\title{
Strategi Pemasaran Produk UMKM di Kecamatan Pamulang Tangerang Selatan - Banten
}

\section{Pusporini}

Universitas Pembangunan Nasional Veteran Jakarta

pusporini61@yahoo.com

\section{Tati Handayani}

Universitas Pembangunan Nasional Veteran Jakarta tatihandayani01@gmail.com

\section{Lina Aryani \\ Universitas Pembangunan Nasional Veteran Jakarta lina.aryani59@gmail.com}

\begin{abstract}
Abstrak
Penelitian ini bertujuan untuk mengetahui strategi pemasaran yang tepat dan berdaya saing yang digunakan UMKM di kecamatan Pamulang. Alat analisis yang digunakan adalah SWOT dengan teknik analisa EFAS/ IFAS untuk mengetahui peluang akses yang berguna untuk pengembangan diri perusahaan dan analisis IFAS/ SAP untuk mengetahui keunggulan strategis yang dimiliki perusahaan. Penelitian dilakukan dengan metode survei di kecamatan Pamulang..UMKM yang diteliti yang berusaha di bidang makanan. Hasil pada penelitian ini yaitu Potensi kekuatan dan kelemahan UMKM di Kecamatan Pamulang sangat baik untuk dicontoh pada pelaku UMKM di wilayah manapun, Strategi Pelaku UMKM di Kecamatan Pamulang berdasarkan potensi yang dimiliki yaitu Strategi Pertumbuhan (Kuadran I), Strategi pemasaran yang dimiliki UMKM di Kecamatan Pamulang dengan Menambah jumlah variasi produk yang ditawarkan, memperluas pangsa pasar., membuat harga yang terjangkau, memberikan diskon khusus pada jumlah pembelian tertentu terutama bagi langgan tetap.
\end{abstract}

Kata Kunci Strategi Pemasaran, SWOT, UMKM

\section{PENDAHULUAN}

Dalam era globalisasi sekarang ini persaingan bisnis menjadi sangat tajam, baik di pasar domestik (nasional) maupun di pasar internasional (global). Perusahaan-perusahaan dihadapkan pada berbagai peluang dan ancaman baik yang berasal dari luar maupun dari dalam negeri. Saat ini perdagangan internasional lebih mengarah pada liberalisasi perdagangan dimana hambatan-hambatan tarif maupun non tarif seperti kuota menjadi semakin berkurang. Bagi perusahaan yang memiliki daya saing dan efisiensi produk yang tinggi, liberalisasi perdagangan merupakan peluang yang besar untuk memenangkan persaingan di tingkat global, sebaliknya bagi perusahaan yang memiliki daya saing dan efisiensi produk yang rendah hal ini merupakan ancaman bagi kelangsungan usaha mereka.

Usaha Mikro Kecil Menengah (UMKM) mempunyai fungsi yang strategis dalam perekonomian nasional, khususnya di wilayah Kota Tangerang Selatan. UMKM berperan 
untuk penyerapan tenaga kerja. Jumlah UMKM yang besar dapat dimanfaatkan menjadi mitra pemerintah dalam mengelola sumber daya. Indonesia sebagai negara dengan jumlah penduduk terbesar ke 4 di dunia harus mampu mengelola sumber daya yang ada untuk kemakmuran rakyat yang sebesar-besarnya .

Di tingkat UMKM liberalisasi perdagangan berimplikasi luas. Usaha Mikro Kecil dan Menengah dituntut untuk melakukan proses produksi dengan produktif dan efisien, serta dapat menghasilkan produk yang sesuai dengan frekuensi pasar global dengan standar kualitas. Kondisi UMKM secara umum di Pamulang memperlihatkan bahwa setiap tahun produk UMKM Pamulang mengalami pertumbuhan dan perkembangan baik pada jenis, desain maupun bahan baku, yang tercipta dari kreativitas dan inovasi para pelaku usaha. Hal ini memerlukan pembinaan dan fasilitasi agar produk-produk tersebut dapat berjaya di pasar lokal dan bersaing di pasar global.

Pemberdayaan ekonomi masyarakat merupakan unsur penting dan utama dalam menciptakan daerah yang mandiri yang dicita-citakan melalui kebijakan desentralisasi. Pembangunan ekonomi daerah dapat diartikan sebagai suatu proses dimana pemerintah daerah dan masyarakatnya mengelola suberdaya yang ada dan membentuk suatu pola kemitraan antara pemerintah daerah dengan sektor swasta untuk menciptakan suatu lapangan kerja baru dan merangsang perkembangan kegiatan ekonoi dalam wilayah tersebut. Oleh karena itu, pemerintah daerah beserta partisipasi masyarakat dengan menggunakan sumberdaya yang ada harus mampu menaksir potensi sumber-sumberdaya yang diperlukan untuk merancang dan membangun perekonomian daerahnya

Dalam rangka upaya pembangunan ekonomi daerah, inventarisasi potensi wilayah/masyarakat/daerah mutlak diperlukan agar dapat ditetapkan kebijakan pola pengebangan baik secara sektoral maupun secara multisektoral. Salah satu langkah inventarisasi/identifikasi potensi ekonomi daerah adalah dengan mengidentifikasi produkproduk potensial, andalan dan unggulan daerah pada tiap-tiap sub sektor. Produk unggulan daerah menggambarkan kemampuan daerahmenghasilkan produk, menciptakan nilai, memanfaatkan sumberdaya secara nyata, memberi kesempatan kerja, mendatangkan pendapatan bagi masyarakat maupun pemerintah, memiliki prospek untuk meningkatkan produktivitas dan investasinya. Sebuah produk dikatakan unggul jika memiliki daya saing sehingga mampu untuk menangkal produk pesaing di pasar domestic dan /atau menembus pasar ekspor.

Peran Usaha Mikro Kecil dan Menengah dinilai sangat mendukung untuk mengurangi angka kemiskinan dan pengangguran. Dapat dibuktikan UMKM menjadi salah satu program pemerintah yang memperkokoh perekonomian. Pemerintah sadar bahwa sepenuhnya kebijakan dukungan tersebut mampu mengkondisikan UMKM Indonesia yang makmur. Maka UMKM dijadikan sebagai pelopor perekonomian di Indonesia. Menjelang MEA, UMKM sudah menjadi tumpuan masyarakat dengan UMKM yang menjadi salah satu usaha yang digemari, yang terbukti penyerapan tenaga UMKM di Depok sebesar 73\% (kompasiana.com).

Untuk bidang kuliner, masyarakat cenderung senang mengkonsumsi jenis makanan yang bervariasi atau memiliki ciri khas tersendiri. Sedangkan bidang fashion mengalami peningkatan, karena masyarakat ingin tampil lebih kekinian dengan fashion yang dikenakannya. Begitu pun untuk bisnis handycraft juga menjadi unggul, karena banyak masyarakat yang memilih untuk menggunakan barang hasil kerajinan tangan. Barang hasil rumahan cenderung lebih menarik dibandingkan yang dihasilkan dengan menggunakan mesin.

Pesatnya perkembangan Kota Tangerang Selatan (Tangsel) ternyata menjadi indikator yang baik bagi pasar kuliner.Pasalnya, Dinas Koperasi dan Usaha Kecil Menengah (UKM) 
Tangerang Selatan mencatat, sampai saat ini terdapat sekira 26.700 UKM di Tangsel.Dari data tersebut, sebagian besar usahanya bergerak di bidang kuliner (warta kota.com)

Perekonomian yang semakin sulit, gaya hidup yang semakin berubah dari zaman ke zaman, kebutuhan individu semakin banyak tetapi sumber pendapatan yang minim atau kecil menuntut para pelaku UMKM untuk berusaha lebih gigih dan kerja keras.

Ketidakmampuan UMKM untuk menghadapi pasar global mungkin timbul karena lemahnya akses terhadap informasi. Kelemahan ini dapat berdampak pada sempitnya peluang pasar dan ketidakpastian harga. Di sini terlihat bahwa era bisnis global menuntut penguasaan informasi inovasi dan kreatifitas pelaku usaha, baik dari aspek teknologi maupun kualitas sumberdaya manusia. Lemahnya kemampuan UMKM dalam mengakses informasi diduga terkait langsung dengan kondisi faktor internal UMKM yang dibayangi oleh berbagai keterbatasan untuk mampu memberikan informasi kepada konsumen. Akibatnya produk UMKM yang sebenarnya memiliki pangsa pasar yang cukup besar di dunia internasional, belum banyak diketahui konsumen. Solusi penting yang perlu dilakukan oleh UMKM untuk mengatasi masalah adalah mengenalkan produk produk UKM tersebut melalui kegiatan promosi.

Segala strategi untuk mencapai hasil penjualan yang tinggi harus ditempuh para pelaku UMKM, demi memenangkan daya saing diantara mereka. Strategi pemasaran adalah alat fundamental yng direncanakan untuk mencapai tujuan perusahaan dengan mengembangkan keunggulan bersaing yang berkesinambungan melalui pasar yang dimasuki dan program pemasaran yang dipergunakan untuk melayani pasar sasaran tersebut (http://www.makassarpreneur.com). Melihat beberapa kenyataan di atas, membuat penulis terinspirasi untuk menganalisis strategi pemasaran yang ada pada UMKM di bidang makanan di Kota Pamulang, untuk selanjutnya dapat diketahui strategi pemasaran yang lebih efektif dan efisien guna meningkatkan daya saing dan pada akhirnya dapat meningkatkan kesejahteraan para pelaku UMKM tersebut.

\section{LANDASAN TEORI}

\section{A. Strategi Pemasaran}

Strategi pemasaran merupakan logika pemasaran yang dengan berdasarkan itu unit bisnis diharapkan dapat mencapai sasaran pemasarannya (Kotler dan Armstrong, 2010) organisasi membutuhkan pemasaran untuk mencapai tujuan dan objektifnya, jadi perusahaan memerlukan strategi yang berbeda-beda guna jangka panjang yang digunakan bagi pedoman masing-masing tingkat perusahaan (Utsalina \& Dewa, 2015). Perusahaan selalu dituntuk untuk melakukan inovasi dalam melakukan strategi bersaing. Dengan adanya perencanaan strategis maka konsepsi perusahaan akan menjadi jelas sehingga dapat membentuk rencana-rencana lain dan dapat mengalihkan sumber -sumber organisasi secara efektif (Krisning \& Chriswahyudi, 2017).

Dengan demikian dapat dikatakan bahwa strategi pemasaran memegang peranan yang penting dalam pemasaran sebagai cara untuk mencapai tujuan perusahaan. Penerapan strategi pemasaran yang baik dan benar akan memberikan efek yang kuat terhadap perusahaan yang sedang berjalan (Krisning \& Chriswahyudi, 2017). Sehingga untuk mewujudkan tujuan perusahaan maka perlu dibentuk dan dibuat strategi pemasaran yang optimal.

Dalam penelitian yang dilakukan oleh (Caroline \& Lahindah, 2018) menyatakan bahwa sebuah strategi pemasaran dapat terdiri dari satu atau lebih program pemasaran; setiap program terdiri dari dua elemen, yaitu target pasar dan bauran pemasaran atau marketing mix. Bauran pemasaran dikenal juga dengan istilah 4P, yaitu product, price, place, dan promotion. Untuk 
mengembangkan strategi pemasaran, organisasi harus memilih kombinasi yang tepat dari target pasar dan bauran pemasaran dalam rangka menciptakan keunggulan kompetitif yang berbeda dari para pesaingnya (Ferrel, 2011).

Persaingan yang ketat saat ini membuat pelaku usaha/perusahaan harus menggunakan strategi-strategi pemasaran yang benar-benar tepat untuk mencapai tujuan yang telah ditetapkan atau untuk mempertahankan kelangsungan hidupnya. Tujuan kegiatan pemasaran disini adalah untuk mempengaruhi konsumen agar bersedia membeli barang atau jasa yang dihasilkan perusahaan di saat mereka membutuhkan. Karena itu suatu perusahaan harus dapat memahami keinginan dan kebutuhan dari konsumen, serta mengetahui strategi-strategi pemasaran yang harus dilakukan agar dapat mencapai tujuan yang diinginkan. Strategi Pemasaran merupakan pengorganisasian segala sumber daya yang dimiliki guna memasarkan suatu produk. (Wawan, 2006). Selanjutnya disebutkan strategi pemasaran yang dilakukan harus memperhatikan bauran pemasaran, daur hidup produk, dan mempertahankan atau memperpanjang tahap kematangan pasar.

\section{B. Daur Hidup Produk}

Daur hidup produk terdiri terdiri dari empat tahap, yaitu perkenalan pasar, pertumbuhan pasar, kematangan pasar, dan penurunan penjualan. Setiap tahapan daur hidup memiliki ciriciri yang berbeda dalam hal laba, biaya, jumlah pesaing, dan tujuan pemasaran. Tahap perkenalan pasar memiliki ciri-ciri : perusahaan tidak memperoleh laba karena biaya yang dikeluarkan untuk memperkenalkan produk ke pasar sangat besar dan jumlah pesaing masih sedikit. Pada tahap ini tujuan pemasaran diarahkan pada menciptakan kesadaran dan keinginan mencoba pada onsumen yang menjadi target pasar.

1. Tahap pertumbuhan pasar memiliki ciri-ciri : penjualan meningkat cepat; biaya mulai menurun sehingga laba usaha mulai meningkat serta jumlah pesaing mulai bertambah. Tujuan pemasaran diarahkan untuk memaksimalkan pangsa pasar.

2. Tahap kematangan pasar memiliki ciri-ciri: penjualan sangat tinggi, biaya rendah sehingga laba usaha tinggi, serta jumlah pesaing banyak dan cenderung mulai berkurang karena persaingan ketat. Pada tahap ini tujuan pemasaran diarahkan untuk mempertahankan pangsa pasar.

3. Tahap penurunan penjualan memiliki ciri-ciri : penjualan menunjukkan kecenderungan menurun, biaya rendah, tetapi laba usaha mulai menurun karena penjualan menurun, serta jumlah pesaing mulai berkurang. Tujuan pemasaran pada tahap ini diarahkan untuk mengurangi pengeluaran agar usaha tetap berjalan.

\section{Mempertahankan Dan Memperpanjang Tahap Kematangan Pasar}

Kelangsungan usaha merupakan suatu hal yang harus dipertahankan. Ketika usaha sudah mencapai tahap kematangan pasar maka harus dilakukan upaya untuk mempertahankan agar daur hidup produk selalu dalam tahap tersebut. Beberapa hal yang harus dilakukan agar tahap kematangan pasar dalam daur hidup produk dapat terus dipertahankan dan diperpanjang : a). Menjaga Kontinuitas suplai; b).Perluasan pasar; c). Melakukan diversifikasi produk; d) Mengembangkan produk value added.

\section{Lingkungan Pemasaran}

Untuk dapat mencapai apa yang di inginkan oleh perusahaan, perlu diperhatikan lingkungan internal dan eksternal. Mengingat kedua faktor tersebut sangat berpengaruh terhadap kebijakan perusahaan dalam kelangsungan kegiatan usahanya. Dengan mncoba 
menggunakan sebaik mungkin dengan cara memanfaatkan kekuatan dan peluang yang ada, serta mengantisipasi gerakan pesaing dan ancaman untuk mendapatkan keuntungan yang maksimal bagi perusahaan (Krisning \& Chriswahyudi, 2017). Lingkungan pemasaran dibagi menjadi dua yaitu lingkungan pemasaran eksternal dan lingkungan pemasaran internal yang mana keduanya akan mempengaruhi kegiatan pemasaran perusahaan.

\section{E. Lingkungan Pemasaran Eksternal}

Keberhasilan ini tergantung dari kemampuan dalam mengelola kedua faktor ini melalui analisis faktor lingkungan serta pembentukan dan pelaksanaan strategi usaha. Dimana Faktorfaktor lingkungan eksternal perusahaan meliputi yaitu (Setyowati, 2016):

1. Demografi, Menurut (Kotler \& Keller, 2016) kekuatan demografis utama yang diamati oleh pemasar adalah populasi, sebab masyarakat merupakan pembentuk pasar. Tanpa adanya masyarakat maka pasar tidak akan terbentuk. Pemasar sangat tertarik pada ukuran dan tingkat pertumbuhan populasi di suatu kota, wilayah, dan negara. Selain itu juga opada bagaimana distribusi usia dan bauran etnis, tingkat pendidikan, pola rumah tangga, serta karakteristik dan gerakan regional. Hal-hal tersebutlah yang masuk kedalam lingkungan Demografi perusahaan yang harus diperhatikan oleh perusahaan.

2. Ekonomi, Lingkungan ekonomi yang termasuk disini menurut (Kotler \& Keller, 2016) adalah pemasar harus memperhatikan tren yang mempengaruhi daya beli, sebab tren tersebut akan memberikan dampak yang kuat terhadap bisnis, terutama untuk produk perusahan yang langsung ditujukan pada konsumen. Daya beli yang tersedia dalam ekonomi tergantung pada penghasilan, harga, tabungan, utang, dan ketersediaan kredit saat ini.

3. Politik dan Hukum, Lingkungan politik dan hukum ini terdiri dari badan hokum, pemerintah, dan kelompok LSM yang mempengaruhi dan membatasi berbagai organisasi maupun perorangan. Namun sering kali juga lingkungan ini menciptakan peluang bagi para pembisnis melalui kebijakan yang dikeluarkan (Kotler \& Keller, 2016).

4. Teknologi, Pemasar harus mempertimbangkan tingkat perubahan teknologi yang kian pesat saat ini, peluang untuk melakukan inovasi, anggran R\&d yang beragam dan semakin banyaknya peraturan yang dikeluarkan pemerintah karena perubahan teknologi (Kotler \& Keller, 2016).

5. Sosial-Budaya, Masyarakat membentuk kepercayaan, nilai dan norma yang menggambarkan besar selera dan preferensi konsumen. Masyarakat menyerap, hamper tidak sadar, pandangan dunia yang mendefinisikan hubungan mereka bagi diri mereka sendiri, orang lain, organisasi, masyarakat, ala., dan alam semesta (Kotler \& Keller, 2016).

6. Suplier, Suplier merupakan bagaian terpenting dalam penjalanan rantai pasokan yang merupakan saluran yang lebih panjang yang membentang dari bahan mentah hingga komponen tersebut dapat menjadi produk akhir yang disalurkan ke pembeli akhir. Dimana supplier adalah penyedia kebutuhan bahan maupun barang yang akan diperjualbelikan oleh pengusaha.

7. Konsumen, Pelanggan adalah komponen utama dari setiap perusahaan. Tanpa adanya pelanggan menjalankan bisnis akan menjadi sekedar isyarat kosong. Tugas yang paling penting dari setiap perusahaan adalah untuk mempertahankan pelanggan. Tujuan utama lain dari setiap organisasi bisnis adalah kepuasan pelanggan. Tanpa adanya kepuasan pelanggan, bisnis tidak dapat tumbuh dan sejahtera (Dhamarani \& Ghina, 2016). 
8. Pesaing. Pesaing sangat mempengaruhi kebijakan bisnis dan strategi yang dilakukan. Dalam setiap launching produk, sebuah perusahaan haruslah memperhatikan perusahaan lain. Tanpa adanya persaingan, pasar bisa menjadi monopoli, sehingga persaingan di pasar menjadi tidak sempurna (Dhamarani \& Ghina, 2016).

9. Distributor, Saluran distribusi yang digunakan untuk menggelar, menjual, atau menyampaikan produk fisik atau jasa kepada pelanggan merupakan peranan yang dilakukan oleh distributor. Sehingga penting bagi para pengusaha untuk memperhatikan distributor yang bekerja sama dengan mereka.

10. Institusi Pemerintah

11. Ketersediaan Tenaga Kerja, Tenaga kerja merupakan bagian penting dari kegiatan pemasaran. Jika sebuah perusahaan tidak memiliki tenaga kerja maka proses produksi hingga penjualan barang atau jasa tidak dapat dilakukan. Untuk itu ketersediaan tenaga kerja ditempat usaha didirikan perlu menjadi perhatian yang utama bagi perusahaan.

12. Kreditor

\section{F. Lingkungan Pemasaran Internal}

Lingkungan internal menurut Musa Hubeis dan Mukhamad Najib (2008: 32) dalam penelitian (Setyowati, 2016) adalah lingkungan organisasi yang berada dalam organisasi dan secara normal memiliki implikasi langsung dan khusus pada perusahaan.

1. Pemasaran

2. Produksi

3. Sumber Daya Manusia

4. Keuangan

5. Research and Development

6. Sistem Informasi

7. Budaya Perusahaan

Sedangkan menurut (Affanddy, 2017) analisis lingkungan internal dilakukan dengan evaluasi secara periodik kekuatan dan kelemahan untuk variabel-variabel yang ada dalam bidang pemasaran yang meliputi:

1. Produk,

Produk terdiri dari keragaman produk, kualitas, desain, fitur, merek, kemasan, ukuran, dan garansi.

2. Harga

Harga yaitu terdiri atas daftar harga, diskon, promo, jangka pembayaran dan syarat kredit

3. Promosi

Promosi yaitu terdiri atas promosi penjualan, iklan, tenaga penjual, public relation,penjualan langsung

4. Distribusi

Lokasi yaitu terdiri atas saluran distribusi, cangkupan, pengelompokan, lokasi, penyimpanan, dan transportasi (Sugiono, 2014).

Analisis situasi diperlukan untuk mengetahui dan mensiasati lingkungan. Lingkungan eksternal dan internal dikaji dan dianalisis menggunakan analisis SWOT. Analisis kekuatan (strength) dan kelemahan (weakness) dikaji dari lingkungan internal perusahaan, sedangkan 
peluang (opportunity) dan ancaman (threat) dipelajari dari lingkungan eksternal perusahaan (Tamamudin, 2012).

\section{METODOLOGI PENELITIAN}

Teknik pengumpulan data yang digunakan di dalam penelitian ini adalah dengan cara menyebarkan kuesioner kepada pengurus UMKM di Kecamatan Pamulang. Dalam penelitian ini, peneliti menggunakan instrumen riset utama dalam mengumpulkan data primer yaitu kuesioner. Kuesioner yang diberikan kepada responden menggunakan skala likert. Skala yang berisi lima tingkat preferensi jawaban.

Teknik analisis data yang dugunakan pada penelitian ini yaitu analisis SWOT yang diikuti dengan pembuatan table IFAS(Internal Strategic Factors Analysis Summary) dan IFAS(eksternal Strategic Factors Analysis Summary). Alat yang dipakai untuk menyususn faktor-faktor strategis perusahaan adalah matrik SWOT. Matrik ini dapat menggambarkan secara jelas bagaimana peluang dan ancaman eksternal yang dihadapi perusahaan dapat disesuaikan dengan kekuatan dan kelemahan yang dimilikinya. Matrik ini dapat menghasilkan empat set kemungkinan alternatif strategis.

1. Strategi SO

Strategi ini dibuat berdasarkan jalan pikiran perusahaan, yaitu dengan memanfaatkan seluruh kekuatan untuk merebut dan memanfaatkan peluang sebesar-besarnya.

2. Strategi ST

Strategi ini menggunakan kekuatan yang dimiliki perusahaan untuk mengatasi ancaman.

3. Strategi WO

Strategi ini ditetapkan berdasarkan pemanfaatan peluang yang ada dengan cara meminimalkan kelemahan yang ada.

4. Strategi WT

Strategi ini didasarkan pada kegiatan yang bersifat defensif dan berusaha meminimalkan kelemahan yang ada serta menghindari ancaman.

\section{HASIL PENELITIAN}

\section{A. Analisis Eksternal Dan Internal Matriks}

Matriks evaluasi internal dan eksternal digunakan untuk menganalisis pengaruh lingkungan internal yang berpengaruh terhadap kekuatan dan kelemahan sedangkan lingkungan eksternal yang berpengaruh terhadap usaha berupa peluang dan ancaman. Berikut ini adalah matriks evaluasi internal dan eksternal pelaku UMKM di Kecamatan Pamulang.

Tabel 4.1. IFE Matriks Pelaku UMKM di Kecamatan Pamulang

\begin{tabular}{|l|c|c|c|c|}
\hline Tabel Internal Strategic Factors Analysis Summary & BOBOT & RATING & NILAI & RANKING \\
\hline Faktor-faktor Strategis InternaL & & & & \\
\hline Kekuatan & 0,079 & 1,733 & 0,137 & 7 \\
\hline Sumber Daya Manusia yang ramah & 0,068 & 3,600 & 0,245 & 1 \\
\hline Keterampilan yang unggul & 0,071 & 2,833 & 0,201 & 6 \\
\hline Lokasi yang strategis & 0,072 & 2,833 & 0,203 & 4 \\
\hline Penetapan harga yang sesuai produk & 0,080 & 2,733 & 0,220 & 2 \\
\hline kualitas produk yang unggul & 0,071 & 2,867 & 0,203 & 5 \\
\hline Layanan yang Fleksibelitas
\end{tabular}




\begin{tabular}{|l|c|c|c|c|} 
Promosi produk & 0,072 & 3,000 & 0,216 & 3 \\
\hline Jumlah & $\mathbf{0 , 5 1 3}$ & & $\mathbf{1 , 4 2 6}$ & \\
\hline Kelemahan & & & & \\
\hline Manajemen Kerja yang Kurang Optimal & 0,068 & 3,833 & 0,261 & 1 \\
\hline Modal yang besar dalam pendirian usaha & 0,072 & 2,567 & 0,185 & 5 \\
\hline $\begin{array}{l}\text { Kompetensi Karyawan dalam mengelola dana tergolong } \\
\text { rendah }\end{array}$ & 0,071 & 1,800 & 0,128 & 6 \\
\hline Belum adanya susunan standar operasional produk & 0,067 & 1,833 & 0,123 & 7 \\
\hline Keterlambatan dalam proses produksi & 0,067 & 2,833 & 0,191 & 4 \\
\hline Proses Pemberian Kompensasi & 0,069 & 2,867 & 0,197 & 3 \\
\hline Proses Menilai Karyawan & 0,073 & 2,967 & 0,216 & 2 \\
\hline Jumlah & $\mathbf{0 , 4 8 7}$ & & $\mathbf{1 , 3 0 0}$ & \\
\hline Total & $\mathbf{1 , 0 0 0}$ & & $\mathbf{2 , 7 2 5}$ & \\
\hline
\end{tabular}

Tabel 4.2. EFE Matriks Pelaku UMKM di Kecamatan Pamulang

Tabel Eksternal Strategic Factors Analysis Summary

\begin{tabular}{|l|c|c|c|c|}
\hline Faktor-faktor Strategis Eksternal & BOBOT & RATING & NILAI & RANKING \\
\hline Peluang & & & & \\
\hline Luasnya pangsa pasar & 0,075 & 3,133 & 0,235 & 3 \\
\hline Kompetitor & 0,083 & 3,000 & 0,249 & 2 \\
\hline memperluas tempat usaha & 0,052 & 3,100 & 0,161 & 7 \\
\hline $\begin{array}{l}\text { pemasok tidak bersaing dengan produk-produk lain dalam } \\
\text { industry }\end{array}$ & 0,084 & 3,133 & 0,262 & 1 \\
\hline Kemampuan pelanggan dalam menekankan harga & 0,071 & 2,967 & 0,212 & 5 \\
\hline Kemampuan pelanggan meningkatkan pelayanan & 0,068 & 2,967 & 0,203 & 6 \\
\hline $\begin{array}{l}\text { Kemampuan pelanggan dalam mengumpulkan informasi } \\
\text { terkait produk }\end{array}$ & 0,078 & 2,800 & 0,219 & 4 \\
\hline Jumlah & $\mathbf{0 , 5 1 1}$ & & $\mathbf{1 , 5 4 0}$ & \\
\hline Ancaman & & & & \\
\hline Perkembangan Teknologi & 0,074 & 3,067 & 0,226 & 2 \\
\hline Munculnya pesaing baru & 0,079 & 3,033 & 0,241 & 1 \\
\hline Mahalnya Bahan Baku & 0,074 & 3,000 & 0,223 & 4 \\
\hline Diferensiasi Produk & 0,068 & 2,900 & 0,196 & 5 \\
\hline Karakteristik Produk, Biaya Tetap yang besar & 0,074 & 3,067 & 0,226 & 3 \\
\hline $\begin{array}{l}\text { Produk pengganti yang kualitasnya hampir sama dengan harga } \\
\text { yang murah }\end{array}$ & 0,052 & 3,233 & 0,170 & 6 \\
\hline Akses saluran distribusi & 0,067 & 1,933 & 0,130 & 7 \\
\hline Jumlah & $\mathbf{0 , 4 8 9}$ & & $\mathbf{1 , 4 1 3}$ & \\
\hline Total & $\mathbf{1 , 0 0 0}$ & & $\mathbf{2 , 9 5 3}$ & \\
\hline
\end{tabular}

Berdasarkan perhitungan IFE dan EFE pada tabel 5 dan 6 di atas, maka diperoleh koordinat analisis internal serta koordinat analisis eksternal yaitu $(0.063 ; 0.064)$ adapun nilai koordinat tersebut diperoleh berdasarkan perhitungan sebagai berikut:

\section{a. Koordinat Analisis Internal}

Koordinat analisis internal ini diperoleh dengan merata-ratanya hasil pengurangan skor total kekuatan dengan skor total kelemahan. Adapun perhitungan koordinat analisis internal adalah sebagai berikut:

$=\underline{\text { (skor total kekuatan-skor total kelemahan })}$

$=\underline{(1,426-1300)}$

$=0.06{ }^{2}$ 


\section{b. Koordinat Analisis Eksternal}

Koordinat analisis eksternal ini diperoleh dengan merata-ratanya hasil pengurangan skor total peluang dengan skor total ancaman. Adapun perhitungan koordinat analisis eksternal adalah sebagai berikut:

$=\underline{\text { (skor total peluang-skor total ancaman })}$

$=\underline{(1.540-1.413)}$

$=0.064^{2}$

Koordinat tersebut kemudian dimasukkan kedalam diagram matriks grand strategy (GS). Sehingga terlihat bahwa berdasarkan koordinat di atas, posisi Pelaku UMKM di Kecamatan Pamulang masuk pada uadran I yang memiliki kategori Pertumbuhan. Adapun matriks grand strategy (GS) yang menggambarkan posisi Pelaku UMKM di Kecamatan Pamulang dapat dilihat pada gambar berikut:

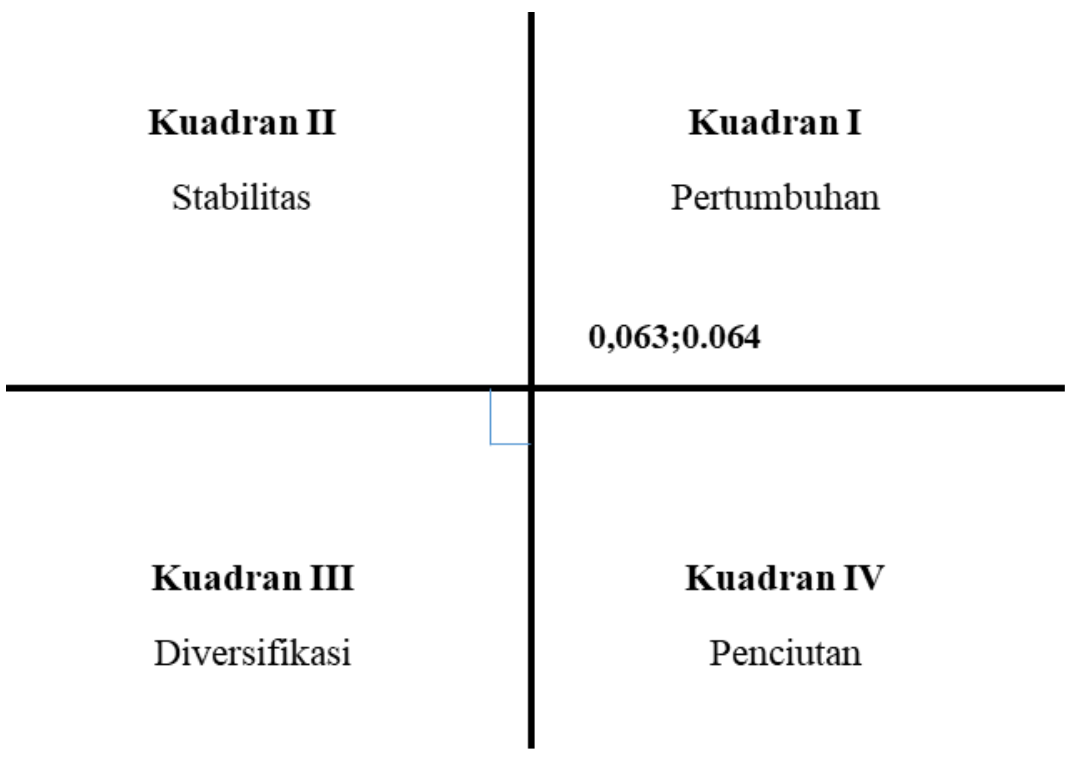

Sumber: data diolah (2021)

\section{Gambar 4.1. Matriks Grand Strategy (GS),Posisi Pelaku UMKM di Kecamatan}

\section{Pamulang}

Pada penelitian ini, para pelaku UMKM di Kecamatan pamulang dikenal dengan kuadran pertumbuhan karena internal usaha kuat dan lingkungan mendukung. Dengan ini usaha dapat mengambil keuntungan dari peluang yang muncul dengan sumber daya kuat yang dimiliki.

\section{B. Tahapan Analisis SWOT}

Berikut ini table yang peneliti gunakan untuk menganalisis dan menentukan keputusan strategis dengan pendekatan matriks SWOT. Matrik ini dapat menggambarkan secara jelas bagaimana peluang dan ancaman eksternal yang dihadapi perusahaan dapat disesuaikan dengan kekuatan dan kelemahan yang dimilikinya. 
Tabel 4. 3. Matriks SWOT Pelaku UMKM di Kecamatan Pamulang

\begin{tabular}{|c|c|c|}
\hline IFAS & $\begin{array}{l}\text { STRENGHTS (S) } \\
\text { 1. Sumber Daya Manusia yang } \\
\text { ramah } \\
\text { 2. Keterampilan yang unggul } \\
\text { 3. Lokasi yang strategis } \\
\text { 4. Penetapan harga yang sesuai } \\
\text { produk } \\
\text { 5. kualitas produk yang unggul } \\
\text { 6. Layanan yang Fleksibelitas } \\
\text { 7. Promosi produk } \\
\text { (Bobot } \mathbf{- 1 . 4 2 )}\end{array}$ & $\begin{array}{l}\text { WEAKNESS }(\mathbf{W}) \\
\text { 1.Manajemen Kerja yang } \\
\text { Kurang Optimal } \\
\text { 2.Modal yang besar dalam } \\
\text { pendirian usaha } \\
\text { 3.Kompetensi Karyawan dalam } \\
\text { mengelola dana tergolong } \\
\text { rendah } \\
\text { 4.Belum adanya susunan } \\
\text { standar operasional produk } \\
\text { 5.Keterlambatan dalam proses } \\
\text { produksi } \\
\text { 6.Proses Pemberian } \\
\text { Kompensasi } \\
\text { 1. Proses Menilai Karyawan } \\
\text { (Bobot - 1.30) }\end{array}$ \\
\hline \begin{tabular}{|l} 
OPPORTUNITIES (O) \\
1. Luasnya pangsa \\
pasar \\
2.Kompetitor \\
3.memperluas tempat \\
usaha \\
4.pemasok tidak bersaing \\
dengan produk-produk \\
lain dalam industry \\
5.Kemampuan pelanggan \\
dalam menekankan \\
harga \\
6.Kemampuan pelanggan \\
meningkatkan \\
pelayanan \\
7.Kemampuan pelanggan \\
dalam mengumpulkan \\
informasi terkait \\
produk \\
(Bobot- 1.54)
\end{tabular} & \begin{tabular}{|l} 
STRATEGI SO \\
1.Menambah jumlah variasi \\
produk yang ditawarkan. \\
2.memperluas pangsa pasar. \\
3.membuat harga yang \\
terjangkau. \\
4. Bemberikan diskon khusus \\
pada jumlah pembelian \\
tertentu terutama bagi \\
langgan tetap. \\
SO (2.96)
\end{tabular} & $\begin{array}{l}\text { STATEGI WO } \\
\text { 1.Meningkatkan efisiensi biaya. } \\
\text { 2.Mengajukan kredit kepada } \\
\text { bank untuk menambah } \\
\text { modal usaha Bekerjasama } \\
\text { dengan teknisi alat } \\
\text { produksi. } \\
\text { 3.Perlu menciptakan focus } \\
\text { bisnis dengan kepemilikan } \\
\text { inovasi produk yang } \\
\text { semakin inovatif. }\end{array}$ \\
\hline \begin{tabular}{|l} 
THREATHS $($ T) \\
1.Perkembangan \\
Teknologi \\
2.Munculnya \\
pesaing baru \\
3.Mahalnya Bahan \\
Baku \\
4.Diferensiasi \\
Produk \\
5.Karakteristik \\
Produk, Biaya \\
Tetap yang \\
besar
\end{tabular} & $\begin{array}{l}\text { STRATEGI ST } \\
\text { 1.Mengembangkan daya } \\
\text { saing. } \\
\text { 2.Meningkatkan pelayanan } \\
\text { kepada pelanggan. } \\
\text { 3.ST }(2.83)\end{array}$ & $\begin{array}{l}\text { STRATEGI WT } \\
\text { 1.Seleksi jasa pengangkutan } \\
\text { yang digunakan. } \\
\text { 2.Perhatian kenyamanan. } \\
\text { 3.Seleksi kualitas karyawan } \\
\text { guna meningkatkan } \\
\text { persaingan. } \\
\text { 4.Menjalin hubungan baik } \\
\text { dengan pelanggan }\end{array}$ \\
\hline
\end{tabular}


6.Produk

pengganti

yang

kualitasnya

hampir sama

dengan harga

yang murah

7.Akses saluran

distribusi

(Bobot-1.41)

\section{Analisis Strategi Pemasaran UMKM Kecamatan Pamulang}

Berikut ini adalah analisis strategi pemasaran UMKM di Kecamatan Pamulang dilihat pada nilai tabel matriks SWOT diatas dengan nilai tertinggi yaitu SO (kekuatanpeluang). Pelaku UMKM di Kecamatan Pamulang dalam meempertahankan pada posisi pertumbuhan hendahnya melakukan:

1. Menambah jumlah variasi produk yang ditawarkan.

2. Memperluas pangsa pasar.

3. Membuat harga yang terjangkau.

4. Bemberikan diskon khusus pada jumlah pembelian tertentu terutama bagi langgan tetap.

\section{KESIMPULAN}

Berdasarkan hasil analisis dan pembahasan yang telah diuraikan pada bab- bab sebelumnya maka dapat disimpulkan bahwa:

a. Potensi kekuatan dan kelemahan UMKM di Kecamatan Pamulang sangat baik untuk dicontoh pada pelaku UMKM di wilayah manapun.

b. Strategi Pelaku UMKM di Kecamatan Pamulang berdasarkan potensi yang dimiliki yaitu Strategi Pertumbuhan (Kuadran I)

c. Strategi pemasaran yang dimiliki UMKM di Kecamatan Pamulang dengan Menambah jumlah variasi produk yang ditawarkan, memperluas pangsa pasar., membuat harga yang terjangkau, memberikan diskon khusus pada jumlah pembelian tertentu terutama bagi langgan tetap.

\section{DAFTAR PUSTAKA}

Abdullah Abidin.2008.Pengembangan Usaha Mikro Kecil Dan Menengah (Umkm) Sebagai Kekuatan Strategis Dalam Mempercepat Pembangunan Daerah.Jurnal Usaha Mikro Kecil Dan Menengah.

Armstrong, Gery Dan Philip Kotler. 2010. Prinsip-Prinsip Pemasaran. Jilid 1. Edisi Kedelapan. Jakarta: Erlangga

Affanddy, M. R. (2017). Perencanaan Strategi Pemasaran Perhiasan Imitasi Dengan Metode Analisis Swot Dan Analytical Hierarchy Process ( Studi Kasus : Ud . Aqila ). Jurnal Matrik, Xviii(1), 61-70.

Caroline, C., \& Lahindah, L. (2018). Analisa Dan Usulan Strategi Pemasaran Dengan Metode Qspm (Studi Kasus Pada Umkm Di Bandung: Pakan Ikan Waringin 
Bandung). Jurnal Sains Pemasaran Indonesia (Indonesian Journal Of Marketing Science), 16(2), 86. Https://Doi.Org/10.14710/Jspi.V16i2.86-102

David Hunger Dan Thomas.2003.Manajemen Strategis. Andi. Yogyakarta

Dhamarani, D. W., \& Ghina, A. (2016). Identif Ication Of Internal And External Environment In Strategy Of. E-Proceeding Of Management, 3(2), 1-9. Retrieved From

Https://Www.Google.Com/Url?Sa=T\&Rct=J\&Q=\&Esrc=S\&Source=Web\&Cd= $11 \&$ Ved=2ahukewix9-

Mxw5pnahvhxdggherwckw4chawmab6bagbeae\&Url=Http\%3a\%2f\%2fjournals. Telkomuniversity.Ac.Id\%2fijm\%2farticle\%2fdownload\%2f1067\%2f726\%2f\&U sg=Aovvaw 1 tsqchzfrhibc3tkwok7sf

Fandy Tjiptono.2002.Strategi Pemasaran.Penerbit Andi.Yogyakarta

Kotler, P., \& Keller, K. L. (2016). Manajemen Pemasaran (13 Jilid I; A. Maulana \& W. Hardani, Eds.). Jakarta: Penerbit Erlangga.

Krisning, T. S., \& Chriswahyudi. (2017). Perencanaan Strategi Pemasaran Dengan Pendekatan Matrik Ie, Swot Dan Ahp Untuk Mendapatkan Alternatif Strategi Prioritas. Jurnal Tenik Industri, (November), 1-2. Retrieved From Jurnal.Umj.Ac.Id/Index.Php/Semnastek

Rosmiati, M. (2016). Penerapan Analisa Swot Dalam Perencanaan Strategis Si/Ti Pada Ajb Bumi Putera Kantor Wilayah Cibinong. Jurnal Techno Nusa Mandiri, Xiii(1), 66-73. Retrieved

From Http://Ejournal.Nusamandiri.Ac.Id/Ejurnal/Index.Php/Techno/Article/Viewfile/2 $67 / 227$

Setyowati, N. W. (2016). Pengaruh Lingkungan Eksternal Dan Lingkungan Internal Terhadap Keunggulan Bersaing Pada Industri Kecil Dan Menengah Di Bandung, Jawa Barat. Esensi, 5(1), 9-26. Https://Doi.Org/10.15408/Ess.V5i1.2330

Sugiono. (2014). Pengaruh Marketing Mix Terhadap Keputusan Pembelian Toyota Avanza Tipe G Di Surabaya. Jurnal Manajemen Pemasaran, 2(1), 1-8.

Sujarweni, V. W., \& Retnani Utami, L. (2015). Analisis Dampak Pembiayaan Dana Bergulir Kur Terhadap Kinerja Umkm. Jurnal Bisnis Dan Ekonomi, 22(1), 11-25. Susilawati, S., \& Yakin, S. H. (2017). Analisis Strategi Pemasaran Makanan Tradisional (Studi Kasus Industri Rengginang Di Kecamatan Sakra Pusat). Jpek (Jurnal Pendidikan Ekonomi Dan Kewirausahaan), 1(1), 19-37. Https://Doi.Org/10.29408/Jpek.V1i1.460

Tamamudin. (2012). Melalui Pendekatan Strategi Pemasaran ( Pendekatan Marketing Mix Dalam Prespektif Islam ). Jurnal Hukum Islam (Jhi), 10(2), 261-276. Retrieved From Http: E-Journal.Stain-Pekalongan.Ac.Id/Index.Php/Jhi

Utsalina, D. S., \& Dewa, W. A. (2015). Strategi Pemasaran Menggunakan Metode Kombinasi Swot Dan Ahp (Studi Kasus : Stmik Pradnya Paramita) Dwi. Smatika Jurnal, 05(02), 1689-1699.

Undang-Undang Republik Indonesia Nomor 20 Tahun 2008 Tentang Usaha Mikro, Kecil, Dan Menengah Dan Undang-Undang Republik Indonesia Nomer 21 Tahun 2008 Tentang Perbankan Syari'ah.

Wawan Purwanto.2006.Strategi Produk, Pemberian Merek Dan Pelayanan Konsumen.Pemasaran Strategi Modul 10 - Pengembangan Merek.Pusat Pengembangan Bahan Ajar Universitas Mercubuana.Jakarta 
Jurnal Ekonomi \& Ekonomi Syariah Vol 3 No 1, Januari 2020

E-ISSN : 2599-3410 | P-ISSN : 4321-1234

DOI : https://doi.org/10.36778/jesya.v3i1.66 